p-ISSN : 2686-1437

e-ISSN : 2686-0201

http://ejournal.ukrida.ac.id/ojs/index.php/Meditek/index

\title{
Gambaran Tingkat Pengetahuan Siswi Kelas 2 SMAN 23 Jakarta tentang Personal Hygiene saat Menstruasi sebelum dan sesudah Penyuluhan
}

\author{
Cindy Sitarani ${ }^{1}$, Flora Rumiati ${ }^{2}$, Erma Mexcorry Sumbayak ${ }^{3}$ \\ ${ }^{1}$ Fakultas Kedokteran dan Ilmu Kesehatan Universitas Kristen Krida Wacana, Jakarta, Indonesia. \\ ${ }^{2}$ Departemen Fisiologi Fakultas Kedokteran dan Ilmu Kesehatan Universitas Kristen Krida Wacana, \\ Jakarta, Indonesia. \\ ${ }^{3}$ Departemen Histopatologi Fakultas Kedokteran dan Ilmu Kesehatan Universitas Kristen Krida \\ Wacana, Jakarta, Indonesia. \\ Alamat Korespondesi: flora.rumiati@ukrida.ac.id
}

\begin{abstract}
Abstrak
Kebersihan organ reproduksi pada remaja sangatlah penting untuk diketahui sejak dini. Kebersihan organ reproduksi dapat disosialisasikan untuk menghindari penyakit-penyakit infeksi yang dapat disebabkan karena kurangnya pengetahuan kebersihan organ reproduksi. Salah satu hal yang dapat dilakukan untuk meningkatkan pengetahuan remaja tentang kebersihan organ reproduksi adalah dengan penyuluhan. Tujuan penelitian ini adalah untuk mengetahui gambaran tingkat pengetahuan pada remaja SMA kelas 2 tentang personal hygiene saat menstruasi sebelum dan sesudah penyuluhan. Metode penelitian yang digunakan adalah metode pre-experimental, dengan one group pre test and post test design. Penentuan sampel dilakukan dengan teknik non-probability sampling yaitu purposive sampling. Sebanyak 90 siswi kelas 2 SMAN 23 Jakarta, berpartisipasi dalam studi ini yang ditetapkan berdasarkan kriteria inklusi dan eksklusi. Hasil penelitian menunjukkan bahwa terdapat peningkatan tingkat pengetahuan sebelum dan sesudah penyuluhan, $(\mathrm{p}<0.05)$ untuk semua variabel yang diteliti, yaitu tentang pengertian menstruasi, perubahan hormonal saat menstruasi dan personal hygiene saat mentruasi. Hal ini menunjukkan adanya pengaruh peningkatan nilai pre test setelah diuji kembali di post test yang dilakukan setelah penyuluhan. Dapat disimpulkan bahwa penyuluhan merupakan salah satu cara yang efektif untuk meningkatkan pengetahuan remaja tentang kebersihan organ reproduksi.
\end{abstract}

Kata kunci: hormon, menstruasi, personal hygiene

\section{Personal Hygiene Knowledge during Menstruation among Senior High School Students in SMAN 23 Jakarta}

\begin{abstract}
Reproductive organ hygiene among adolescent schoolgirls is should be known as early as possible. Personal hygiene can be socialized to avoid infectious diseases due to lack of knowledge of reproductive organs hygiene. One of the things that can be done to improve personal hygiene of the reproductive organs is by counseling. This research was conducted to determine the level of knowledge on personal hygiene during menstruation before and after counseling. The study was carried out using one group pre-test and post-test design. Samples were determined based on a non-probability sampling. Ninety female students of SMAN 23 Jakarta were asked to fill up questionnaires about menstrual hygiene which was carried out before and after counseling. Results showed a significant difference ( $p$ $<0.05)$ on the level of knowledge regarding personal hygiene before and after the counseling. The significant differences were observed for all variables studied, including understanding of menstruation, hormonal changes during menstruation and personal hygiene during menstruation. These results indicate that counseling can be recommended as an effective tool to spread information on reproductive organ hygiene among schoolgirls.
\end{abstract}

Keywords: hormone, menstruation, personal hygiene, 


\section{Pendahuluan}

Pengetahuan dini akan fungsi reproduksi sangat penting bagi remaja, karena dasar pengetahuan akan fungsi reproduksi akan menentukan kehidupan remaja saat dewasa nantinya. ${ }^{1}$ Menurut World Health Orgnization (WHO), remaja adalah seorang individu dengan rentang usia 10-19 tahun. Di dunia terdapat sekitar 1,2 milyar remaja atau sekitar $18 \%$ dari total jumlah penduduk. ${ }^{2}$ Menurut Peraturan Menteri Kesehatan RI No. 25 tahun 2014, remaja adalah seorang individu dengan rentang usia 10-18 tahun, sedangkan menurut Badan Kependudukan dan Keluarga Berencana (BKKBN) rentang usia untuk remaja adalah 10-24 tahun dan belum menikah. ${ }^{2}$

Pengetahuan akan fungsi reproduksi bagi remaja merupakan masalah penting yang perlu mendapatkan perhatian dari semua pihak. ${ }^{3}$ Kesehatan reproduksi tidak semata mengenai struktur biologis reproduksi laki-laki dan perempuan akan tetapi merupakan kondisi yang meliputi kesehatan fisik, mental, dan sosial, juga meliputi pengetahuan akan sistem dan fungsi reproduksi, personal hygiene reproduksi, penyakit yang dapat ditimbulkan, serta mitos-mitos seksualitas. ${ }^{1}$

Pengetahuan tentang menstruasi dan hormon-hormon yang berpengaruh juga perlu dimengerti oleh remaja putri. Pada saat menjelang sampai terjadinya menstruasi akan timbul gejala fisik, psikologis, dan emosional yang diakibatkan oleh perubahan hormonal. Biasanya akan terjadi beberapa hari sebelum menstruasi dan akan hilang beberapa hari saat menstruasi terjadi, namun juga terkadang terjadi terus menerus sampai menstruasi selesai. ${ }^{4}$

Perubahan hormonal akan menimbulkan premenstrual syndrome (PMS) yang disebabkan oleh naik dan turunnya kadar hormon selama terjadinya siklus menstruasi. Hal ini akan memengaruhi perasaan perempuan secara fisik maupun secara emosional. ${ }^{5}$ Selain adanya perubahan emosi yang naik-turun secara tiba-tiba, pada saat menstruasi juga akan terjadi perubahan-perubahan secara fisik seperti mudah pusing, sakit kepala, payudara yang terasa nyeri dan lebih kencang, badan terasa pegal-pegal, merasa lebih gemuk dari biasanya, ada rasa mual, kembung, adanya retensi air di dalam perut, juga timbulnya jerawat saat periode haid datang. ${ }^{4}$ Namun, tidak semua perempun mengalami PMS, gejala ini hanya akan terjadi pada beberapa perempuan yang peka terhadap perubahan hormon.

Pendidikan dini tentang personal hygiene reproduksi pada remaja merupakan langkah awal untuk meningkatkan pengetahuan remaja tentang kesehatan reproduksi. Pendidikan dini mengenai personal hygiene merangkum pengetahuan, sikap, dan perilaku proaktif untuk memelihara dan mencegah risiko terjadinya penyakit, melindungi diri dari ancaman penyakit. $^{3}$ Personal hygiene mengenai reproduksi terutama saat menstruasi contohnya dapat dilakukan dengan cara mengganti pembalut setiap 4 jam sekali dalam sehari. Setelah mandi atau buang air, daerah kewanitaan dikeringkan dengan tisue atau handuk agar tidak lembab. Rajin mengganti pakaian dalam dan menggunakan celana dalam yang baik terbuat dari bahan yang mudah menyerap keringat. ${ }^{3}$

Remaja putri rentan terkena infeksi organ reproduksi yang disebabkan oleh kurang tepatnya perilaku dalam merawat kebersihan diri terutama saat mengalami menstruasi, mereka pada umumnya memiliki tingkat perhatian yang rendah terkait kesehatan reproduksi. ${ }^{6}$ Berdasarkan data yang dihimpun dari Badan Pusat Statistik dan Badan Perencanaan Pembangunan Nasional tahun 2010 di Indonesia terdapat 63 juta remaja berisiko melakukan perilaku yang tidak sehat seperti kurangnya tindakan merawat kebersihan organ reproduksi saat sedang menstruasi. Angka kejadian penyakit infeksi yang terjadi pada saluran reproduksi pada remaja (10-18 tahun) yaitu 35 sampai 42 persen dan dewasa muda (18-22 tahun) sebesar 27 hingga 33 persen. Dalam penelitian yang dilakukan oleh Rahmatika (2010) terungkap bahwa faktor pemicu kasus infeksi saluran reproduksi antara lain imunitas yang rendah sejumlah $10 \%$, perilaku kurang dalam merawat kebersihan diri ketika menstruasi sejumlah $30 \%$, keadaan lingkungan buruk dan tata cara dalam penggunaan pembalut yang kurang tepat ketika menstruasi sejumlah 50\%. ${ }^{6}$ Di dunia, angka kejadian penyakit akibat infeksi alat reproduksi diperkirakan sekitar 2,3 juta pertahun di mana sekitar 1,2 juta diantaranya ditemukan di Negara berkembang. Data di Indonesia mengenai jumlah penderita Infeksi Saluran Reproduksi (ISR) dan Infeksi Menular Seksual (IMS) belum ada. Namun, diprediksi penderita terbesar IMS kebanyakan berusia 1529 tahun, 7 dari 10 orang penderita IMS 
berusia 15-24 tahun. Berdasarkan data dari Badan Kependudukan dan Keluarga Berencana (BKKBN), perempuan Indonesia yang mengalami keputihan sekitar $75 \%$ dengan bacterial vaginosis (BV) yang paling sering menyebabkan keputihan patologis $(40 \%-50 \%$ kasus infeksi vagina). ${ }^{7}$

Penelitian yang dilakukan oleh Fatimah (2016) menunjukkan bahwa dari 40 responden sebagian besar responden memiliki pengetahuan dalam kategori cukup, yakni sebanyak 20 orang $(50,0 \%)$, pengetahuan dalam kategori baik sebanyak 17 orang $(42,5 \%)$, dan pengetahuan dalam kategori kurang sebanyak 3 orang $(7,5 \%){ }^{8}$

Penelitian serupa yang dilakukan di Makasar oleh Nur Rahmawati (2016) menunjukkan bahwa sebagian besar responden yaitu sebanyak 32 responden $(47,8 \%)$ memiliki pengetahuan yang baik tentang pengertian menstruasi dan hanyak sebanyak 10 responden $(14,9 \%)$ yang memiliki pengetahuan yang kurang tentang menstruasi. ${ }^{7}$ Dalam penelitian ini mayoritas responden memiliki pengetahuan baik tentang pengertian menstruasi karena pengetahuan siswa tentang menstruasi dapat diperoleh melalui pendidikan kesehatan, penyuluhan, pengalaman, serta media informasi tentang menstruasi. Berdasarkan hasil penelitian tersebut sebagian besar responden memiliki tingkat pengetahuan yang baik dipengaruhi oleh sumber informasi yang diperoleh dan pelajaran yang mereka dapatkan di sekolah, salah satunya mata pelajaran biologi yang membahas seputar sistem reproduksi termasuk menstruasi. ${ }^{7}$

Tingginya prevalensi remaja dengan penyakit reproduksi akibat kurangnya pengetahuan tentang reproduksi dan personal hygiene pada beberapa penelitian terkait menjadi dasar dilakukannya penelitian ini.

\section{Metode Penelitian}

Desain penelitian ini menggunakan studi eksperimental dengan pendekatan pre eksperimental (one group pre test and post test design). Tempat dilakukannya penelitian ini adalah di SMAN 23 Jakarta, dengan waktu penelitian pada awal Februari 2020.

Populasi dari penelitian ini adalah semua siswi SMA kelas 2 yang sedang bersekolah di SMAN 23 Jakarta, pada bulan Februari 2020. Sampel diambil sesuai dengan kriteria inklusi dan eksklusi yang ditentukan. Kriteria inklusi meliputi siswi SMA kelas 2 yang sedang bersekolah di SMAN 23 Jakarta pada bulan Februari 2020, siswi SMA yang telah menarche (mendapatkan menstruasi pertama), siswi yang bersedia secara informed consent dalam mengisi kuesioner, dan siswi yang kooperatif. Sedangkan kriteria eksklusinya adalah siswi yang tidak bersedia mengisi kuesioner dengan lengkap.

Variabel terikat pada penelitian ini adalah tingkat pengetahuan sebelum dan sesudah menstruasi, sedangkan variabel bebasnya adalah pengetahuan tentang menstruasi, perubahan hormon saat menstruasi dan personal hygiene saat menstruasi. Pengukuran parameter tingkat pengetahuan tentang menstruasi, perubahan hormon dan personal hygiene dengan menggunakan kuesioner yang sudah divalidasi.

Teknik sampling yang digunakan dalam penelitian ini adalah dengan menggunakan metode non-probability sampling yaitu purposive sampling, dimana sampel diambil sesuai dengan tujuan penelitian dengan melihat kriteria inklusi dan eksklusi yang telah ditetapkan, dengan besar sampel sebesar 90 orang. Perhitungan besar sampel minimal mengikuti rumus berikut :

$$
n=\left[\frac{Z \propto+Z \beta) \cdot s^{2}}{(x 1-x 2)}\right]^{2}
$$

dengan:

$\mathrm{n} \quad=$ Jumlah minimum sampel yang dibutuhkan

$\mathrm{Z} \propto=$ Kesalahan tipe $\mathrm{I}$ di tetapkan sebesar $5 \% . \mathrm{Z} \propto=1.96$

$\mathrm{Z} \beta=$ Kesalahan tipe II ditetapkan sebesar $10 \% . \mathrm{Z} \beta=0.84$

$\mathrm{S}^{2}=$ Varian

$\mathrm{x} 1-\mathrm{x} 2=$ Selisih minimal rerata yang dianggap bermakna.

Pada penelitian sebelumnya oleh Sari di Surakarta, ${ }^{9}$ didapatkan nilai $\mathrm{x} 1=$ 86.15 dan $\mathrm{x} 2=75.15$. dengan Standar Deviasi $=6,1$

Berdasarkan rumus sampel di atas, maka besar sampel yang dibutuhkan pada penelitian ini adalah:

$$
\begin{aligned}
n & =\left[\frac{(1.96+0.84) \cdot 6,1^{2}}{(86,15-75,15)}\right]^{2} \\
& =(9,47)^{2} \\
& =89,68=90 \text { orang }
\end{aligned}
$$




\section{Kaji Etik}

Penelitian ini dinyatakan telah lolos kaji etik dengan nomor 930/SLKE-IM/UKKW /KE/FKIK/II/2020 dari Komite Etik Penelitian Medis dan Kesehatan Fakultas Kedokteran Universitas Kristen Krida Wacana.

\section{Hasil dan Pembahasan}

Penelitian dilakukan terhadap 90 sampel yang ada, dengan mengisi kuesioner sebelum dan sesudah dilakukan penyuluhan, didapatkan hasil sebagai berikut:

Berdasarkan tabel 1, mayoritas mendapatkan menarche pada usia 13 tahun $34,4 \%$ maka dapat disimpulkan bahwa pada responden memiliki usia menarche yang sesuai yaitu kurang lebih usia 14 tahun.

Penelitian yang dilakukan oleh Nur Rahmawaty (2016) didapatkan hasil yang sejalan di mana rata-rata usia menarche pada siswi terjadi pada usia normal. Usia menarche juga memengaruhi tingkat pengetahuan anak mengenai personal hygiene dikarenakan adanya pengalaman dan pengetahuan lebih yang didapatkan dari haid pertama yang terjadi. $^{7}$

\section{Tabel 1. Karateristik Responden Penelitian}

\begin{tabular}{lcc}
\hline $\begin{array}{l}\text { Kelompok } \\
\text { Menarche } \\
\text { (Usia- }\end{array}$ & Frekuensi & $\begin{array}{c}\text { Persentase } \\
(\%)\end{array}$ \\
Tahun) & & \\
\hline 10 & 3 & 3,3 \\
11 & 16 & 17,8 \\
12 & 25 & 27,8 \\
13 & 31 & 34,4 \\
14 & 14 & 15,6 \\
15 & 1 & 1,1 \\
\hline
\end{tabular}

Tabel 2. Distrubusi Responden Berdasarkan Hasil Pre Test dan Post Test tentang Pengertian Menstruasi

\begin{tabular}{|c|c|c|c|c|c|}
\hline \multirow[t]{2}{*}{$\begin{array}{l}\text { Pengertian } \\
\text { Menstruasi }\end{array}$} & Frekuensi & Persentase $(\%)$ & Frekuensi & Persentase $(\%)$ & \multirow[t]{2}{*}{ p Value } \\
\hline & \multicolumn{2}{|c|}{ Pre Test } & \multicolumn{2}{|r|}{ Post Test } & \\
\hline Baik & 41 & 45,6 & 76 & 84,4 & \\
\hline Cukup & 41 & 45,6 & 14 & 15,6 & 0,000 \\
\hline Buruk & 8 & 8,9 & 0 & 0,0 & \\
\hline
\end{tabular}

Berdasarkan tabel 2, didapatkan kenaikan hasil dari 41 responden $(45,6 \%)$ dengan hasil pre test baik meningkat menjadi 76 responden $(84,4 \%)$. Dan dari 8 responden $(8,9 \%)$ dengan pre test buruk menurun menjadi 0 responden $(0,0 \%)$ dengan post test buruk. Hal ini menunjukkan bahwa terjadi peningkatan pengetahuan tentang pengertian menstruasi sebelum dan sesudah dilakukan penyuluhan.

Penelitian ini sesuai dengan penelitian yang dilakukan oleh Shanti dan Yuniarti (2014) yang mendapatkan hasil sebagian besar remaja putri di SMA Negeri 1 Melati Sleman Yogyakarta mempunyai tingkat pengetahuan yang baik mengenai pengertian menstruasi. ${ }^{3}$ Penelitian yang juga dilakukan oleh Mila, Akmal, dan Indar (2014) menunjukkan bahwa 55,4\% siswi mempunyai pengetahuan yang baik mengenai pengertian menstruasi pada remaja. ${ }^{10}$
Setiap anak akan melewati masa pubertas yaitu masa dimana seorang anak akan mengalami perubahan-perubahan secara fisik, psikis dan juga kematangan fungsi reproduksi atau seksualitas. Pada saat seperti ini anak akan berubah menjadi remaja dan akan mengalami perubahan yaitu timbulnya ciri-ciri kelamin sekunder, menarche atau haid pertama kali dan juga perubahan secara psikis. ${ }^{11}$ Pubertas juga ditandai dengan adanya menstruasi. Menstruasi merupakan keluarnya darah dari lubang vagina yang terjadi secara periodik dan siklik yang berasal dari luruhnya (deskuamasi) uterus atau dinding rahim (endometrium). ${ }^{12,13}$

Dalam penelitian yang dilakukan terdapat banyak responden yang sudah paham terhadap pengertian menstruasi, terlebih lagi setelah diberikan penyuluhan. Dalam hal ini responden sudah berada pada tahap memahami (compherension) yang merupakan kemampuan 
seseorang untuk memberi penjelasan tentang suatu objek yang diketahui secara benar, dan dapat menginterpretasikan materi objek tersebut dengan benar. ${ }^{14}$

Tingkat pengetahuan merupakan salah satu hal yang penting untuk seseorang dapat membentuk suatu tindakan (over behaviour). Perilaku yang didasari oleh adanya pengetahuan akan jauh lebih baik daripada perilaku yang tidak sama sekali didasari dengan pengetahuan. ${ }^{15}$ Banyak cara yang dapat dilakukan siswi untuk mendapatkan pengetahuan tentang menstruasi yaitu dapat diperoleh dari pendidikan kesehatan. Adapun contohnya penyuluhan seperti yang dilakukan dalam penelitian ini, pengalaman yang bisa didapat dari orang tua ataupun orang-orang di lingkungan sekitarnya, membaca melalui media elektronik, majalah, dan buku tentang kesehatan. ${ }^{16}$ Terbukti dari adanya penyuluhan yang dilakukan, terjadi peningkatan pengetahuan tentang menstruasi pada siswi SMAN 23 Jakarta. Selain penyuluhan yang diberikan, pengetahuan siswi juga kemungkinan didapatkan dari pengalaman, yang ditunjukkan dari hasil usia menarche sebagian besar berusia 11-13 tahun.

\section{Tabel 3. Distribusi Responden Berdasarkan Hasil Pre Test dan Post Test tentang Perubahan Hormon Saat Menstruasi}

\begin{tabular}{lccccc}
\hline $\begin{array}{l}\text { Perubahan } \\
\text { Hormon }\end{array}$ & \multirow{2}{*}{ Frekuensi } & Persentase (\%) & Frekuensi & Persentase (\%) & p Value \\
& \multicolumn{2}{c}{ Pre Test } & \multicolumn{2}{c}{ Post Test } & \\
\hline Baik & 45 & 50,0 & 85 & 94,4 & \\
Cukup & 41 & 45,6 & 5 & 5,6 & 0,000 \\
Buruk & 4 & 4,4 & 0 & 0,0 & \\
\hline
\end{tabular}

Berdasarkan tabel 3, didapatkan kenaikan hasil dari 45 responden $(50,0 \%)$ dengan hasil pre test baik meningkat menjadi 85 responden $(94,4 \%)$ dan dari 4 responden $(4,4 \%)$ dengan pre test buruk menurun menjadi $0 \quad(0,0 \%)$ responden dengan post test buruk. Hasil di atas menunjukkan bahwa terdapat peningkatan pengetahuan tentang perubahan hormon saat menstruasi pada siswi remaja sebelum dan sesudah penyuluhan dilakukan.

Hasil dari pre test penelitian ini sejalan dengan penelitian yang telah dilakukan oleh Siti Nina (2014) menyatakan bahwa sebagian besar remaja putri memiliki pengetahuan yang buruk mengenai perubahan fisik yang dipengaruhi oleh hormonal sebanyak 47 responden
$(52,2 \%) .{ }^{17}$ Dan penelitian ini juga dilakukan oleh Hani, Kusminatum, dan Dwi (2016) didapatkan hasil 17 responden $(32,7 \%)$ memiliki pengetahuan kurang. ${ }^{11}$

Dengan adanya tingkat pengetahuan yang baik pada siswi remaja putri tentang perubahan hormon yang terjadi sebelum dan saat menstruasi, diharapkan para remaja dapat siap dan tidak bingung atau kaget dengan perubahan yang terjadi akibat aktivitas hormon setiap siklus haid terjadi. Tidak semua akan mengalami gejala perubahan hormon yang sama tetapi bagi sebagian perempuan akan merasa terganggu dengan adanya gejala tersebut dan berakibat mengganggu aktivitas seseorang.

Tabel 4. Distribusi Responden Berdasarkan Hasil Pre Test dan Post Test tentang Personal Hygiene saat Menstruasi

\begin{tabular}{lccccc}
\hline $\begin{array}{l}\text { Personal } \\
\text { Hygiene }\end{array}$ & $\begin{array}{c}\text { Frekuensi } \\
\text { Pre Test }\end{array}$ & $\begin{array}{l}\text { Persentase } \\
\text { (\%) }\end{array}$ & Frekuensi & Persentase (\%) & p Value \\
& \multicolumn{2}{c}{ Post Test } & \\
\hline Baik & 65 & 72,2 & 88 & 97,8 & \\
Cukup & 22 & 24,4 & 2 & 2,2 & 0,000 \\
Buruk & 3 & 3,3 & 0 & 0,0 & \\
\hline
\end{tabular}


Berdasarkan tabel 4, didapatkan kenaikan hasil dari 65 responden $(72,2 \%)$ dengan hasil pre test baik meningkat menjadi 88 responden $(97,8 \%)$. Serta hasil pre test buruk didapatkan 3 responden $(3,3 \%)$ menurun menjadi 0 responden dengan post test buruk. Dari data diatas dapat kita simpulkan bahwa terdapat peningkatan pengetahuan pada siswi SMAN 23 Jakarta mengenai personal hygine saat menstruasi sebelum dan sesudah diberikan penyuluhan.

Hasil penelitian sebelum penyuluhan ini, sejalan dengan penelitian yang dilakukan oleh Rahmatika (2010) yang didapatkan hasil bahwa di SMK Negeri 8 Medan menunjukan bahwa tingkat pengetahuan remaja putri yang kurang terhadap pengetahuan personal hygine saat menstruasi. ${ }^{18}$ Dari penelitian yang juga dilakukan oleh Erina Ike (2012) menyatakan bahwa siswi dengan pengetahuan baik sebelum dilakukan penyuluhan hanya sebesar 5 responden $(18,5 \%)$ dan setelah diberikan penyuluhan meningkat menjadi 22 responden $(81,5 \%) .{ }^{19}$ Hasil yang didapatkan juga sejalan dengan penelitian yang dilakukan oleh Yessy (2017) yang menyatakan adanya peningkatan pengetahuan sebelum dan sesudah dilakukan penyuluhan. ${ }^{9} \quad$ Peningkatan yang terjadi diakibatkan oleh siswi yang sudah tahu dan juga memahami tentang personal hygiene. Tahu (know) yang berarti mengingat/mengetahui suatu materi yang telah dipelajari sebelumnya dan memahami (comprehension) adalah suatu kemampuan untuk paham sehingga dapat menjelaskan secara benar tentang objek yang diketahui dan dapat menginterpretasikan dengan benar. ${ }^{14}$

Walaupun penelitian ini dilakukan di kota besar (Jakarta) dan tingkat pendidikan berbeda (SMA), dan usia menarche terbanyak pada usia 13 tahun, ternyata sebelum dilakukan penyuluhan didapatkan juga tingkat pengetahuan tentang mentruasi, perubahan hormonal dan personal hygiene dengan hasil cukup dan kurang, yang setelah dilakukan penyuluhan terjadi peningkatan menjadi baik.

Personal Hygine merupakan suatu tindakan perlindungan diri yang didasari oleh pengetahuan untuk menjaga kesehatan, kebersihan, dan untuk mencegah risiko penyakit. Personal hygiene saat menstruasi sangatlah penting untuk perempuan khususnya remaja yang baru mengalami menstruasi untuk menjaga kebersihan daerah kewanitaan dan mencegah penyakit infeksi yang dapat terjadi jika tidak menjaga kebersihaan vagina. ${ }^{20}$ Dengan adanya penyuluhan dapat mencegah ketidaktahuan remaja akan kebersihan organ reproduksi dan agar remaja lebih waspada akan penyakit-penyakit yang akan terjadi jika tidak menjaga kebersihan.

Tindakan yang harus dilakukan setiap perempuan terutama remaja dalam menjaga kebersihan daerah kewanitaannya adalah dengan mengganti pembalut minimal 4 kali dalam sehari, tidak menggunakan wc yang jorok, mandi untuk menjaga kebersihan tubuh, jangan menggunakan pakaian dalam yang lembab dan juga ketat, serta selalu membersihkan daerah kewanitaan dengan tisu lembut dan dengan cara ditepuk. ${ }^{21}$ Organ genital merupakan organ yang sangat sensitif sehingga butuh perhatian khusus tentang kesehatan dan juga kebersihannya agar terhindar dari penyakit dengan cara menerapkan personal hygiene terutama saat sedang menstruasi berlangsung

Terdapat banyak penyakit yang dapat terjadi akibat tidak menjaga personal hygiene seperti dapat terjadinya infeksi saluran kemih (ISK), penyakit radang panggul, dan yang paling sering terjadi adalah keputihan abnormal. Banyaknya darah yang menumpuk di pembalut mengharuskan wanita mengganti pembalut setiap 4-5 jam sekali dikarenakan darah merupakan media yang baik untuk tumbuhnya kuman patogen ditambah lagi suasana lembab dikarenakan pembalut yang terlalu lama dipakai. ${ }^{21,22}$

Ketiga variabel bebas, pengetahuan tentang menstruasi, perubahan hormonal dan personal hygiene memiliki perbedaan bermakna antara sebelum dan sesudah penyuluhan. Uji perbandingan menggunakan Uji t-test berpasangan karena data numerik yang akan diuji telah terdistribusi normal. Hasil uji t-test berpasangan untuk setiap variable menunjukkan $\mathrm{p}<0,05$ yang berarti adanya pengaruh peningkatan nilai pre test setelah diuji kembali di post test setelah diselenggarakan penyuluhan.

Adapun faktor usia dan juga pengalaman dapat memengaruhi tingkat pengetahuan seseorang. ${ }^{23}$ Dengan adanya penyuluhan yang diberikan setelah pre test memberikan pengaruh terhadap tingkat pengetahuan saat dilakukan post test. Penyuluhan merupakan salah satu sarana untuk menyebarkan informasi 
untuk memberi pengetahuan dan pengalaman lebih banyak agar dapat diterapkan pada diri seseorang. ${ }^{24}$

Pada penelitian ini terdapat kekurangan dengan tidak dibahasnya pengaruh faktorfaktor lain yang kemungkinan juga berpengaruh terhadap tingkat pengetahuan siswa terhadap personal hygiene saat menstruasi, seperti tingkat pendapatan dan pendidikan orang tua, akses terhadap informasi kesehatan, juga pengaruh lingkungan sekitar.

\section{Simpulan}

Berdasarkan penelitian yang dilakukan mengenai gambaran tingkat pengetahuan siswi kelas 2 SMAN 23 Jakarta tentang personal hygiene sebelum dan sesudah penyuluhan, didapatkan hasil yaitu adanya peningkatan pengetahuan remaja putri tentang pengertian menstruasi sebelum dilakukan penyuluhan dan sesudah penyuluhan. Sebanyak $8 \quad(8,9 \%)$ responden memiliki pengetahuan buruk sebelum dilakukan penyuluhan. Terdapat peningkatan pengetahuan remaja putri tentang perubahan hormon saat menstruasi, sebelum dilakukan penyuluhan sebanyak 4 responden $(4,4 \%)$ memiliki pengetahuan yang buruk. Terdapat peningkatan pengetahuan remaja putri tentang personal hygiene saat menstruasi, sebelum dilakukan penyuluhan sebanyak 65 responden $(72,2 \%)$ memiliki pengetahuan baik dan setelah dilakukan penyuluhan meningkat menjadi $88(97,8 \%)$ responden. Jadi disarankan bagi remaja putri untuk dapat mempraktikkan penyuluhan yang sudah diberikan pada keseharian untuk mencegah faktor risiko penyakit infeksi. Saran untuk penelitian selanjutnya diharapkan dapat dilihat juga pengaruh faktor ekonomi dan faktor pendidikan orang tua terhadap pengetahuan kebersihan organ reproduksi.

\section{Daftar Pustaka}

1. Indah IL. Gambaran pengetahuan remaja putri tentang personal hygiene di SMPIT As Salam Pasar Minggu. Universitas Indonesia; 2012. Skripsi

2. Kementerian Kesehatan Indonesia. Infodatin: Situasi kesehatan reproduksi remaja. KEMENKES; 2015.

3. Lianawati I. Tingkat pengetahuan remaja putri tentang personal hygine saat menstruasi pada siswi kelas X SMA Islam Terpadu Al-Masyhur Pati. Surakarta; 2012.

4. Weatherspoon D. Creating a personal hygiene routine: tips and benefits. Healthline; 2018.

5. Erdita L. Tingkat pengetahuan remaja putri tentang perubahan fisik pubertas di SMAN 1 Sambi Kabupaten Boyolali. Sekolah Tinggi Ilmu Kesehatan Kusuma Husada Surakarta; 2013. Skripsi

6. Pythagoras KC. Personal hygiene remaja putri ketika menstruasi. Jurnal Promkes. 2017;5(1).

7. Agra NR. Gambaran pengetahuan remaja putri tentang personal hygiene saat menstruasi pada siswi SMA Negeri 1 Sungguminasa tahun 2016. UIN Alaluddin Makassar; 2016. Skripsi

8. Fatimah R. Gambaran pengetahuan remaja putri tentang kebersihan alat kelamin pada saat menstruasi di SMU N 2 Kendari. Politeknik Kesehatan Kendari; 2016.

9. Sari YL. Pengaruh penyuluhan personal hygiene terhadap pengetahuan dan sikap personal hygiene saat menstruasi pada siswi kelas VII di SMP Negeri 5 Karanganyar. Universitas Muhammadiyah Surakarta; 2017.

10. Wiretno M, Akmal, Indar. Hubungan antara tingkat pengetahuan menstruasi terhadap upaya penanganan dismenore pada siswi SMA Negeri 1 Bungku Tengah. Jurnal Kesehatan. 2014;5(5).

11. Latifah H, Kusminatum, Ratnaningsih D. Tingkat pengetahuan pubertas pada remaja putri kelas VIII di SMP Muhammadiyah III Depok Sleman. Jurnal Permata Indonesia. 2016;7(1).

12. Anwar M, Baziad A, Probowo P. Buku ilmu kandungan. Ed 3. Jakarta: PT. Bina Pustaka Sarwono Prawirohardjo; 2011.

13. Sinaga E, Saribanon N, Suprihatini. Managemen kesehatan menstruasi. Universitas Nasional; 2017.

14. Notoatmodjo, Soekidjo. Pengembangan sumber daya manusia. Jakarta: PT. Rineka Cipta; 2015.

15. Dhuangga, Wandha. Efektifitas pendidikan kesehatan tentang personal hygiene kewanitaan terhadap pengetahuan dan sikap remaja putri dalam menangani keputihan. Jurnal Ners Indonesia. 2012;2(2)

16. Suryati B. Perilaku kebersihan remaja saat menstruasi. Jurnal Health Quality. 2012;3(1). 
17. Nina S. Gambaran pengetahuan dan sikap remaja puteri dalam menghadapi perubahan fisik saat pubertas di pondok pesantren AlBaqiyatussholihat. Universitas Islam Negri Syarif Hidayatullah Jakarta; 2014. Skripsi

18. Rahmatika, Dwi. Pengaruh pengetahuan dan sikap tentang personal hygiene menstruasi terhadap tindakan personal hygiene remaja putri pada saat menstruasi di SMK Negeri 8 Medan tahun 2010. FKM Universitas Sumatera Utara; 2010.

19. Sulistyawati EI. Pengaruh penyuluhan terhadap pengetahuan remaja putri tentang personal hygiene organ reproduksi di SMP Negeri 1 Gesi Sragen. Universitas Sebelas Maret Surakarta; 2012.
20. Septiana, Lina. Hubungan pengetahuan remaja putri tentang personal hygiene kewanitaan dengan pelaksanaan personal hygiene kewanitaan pada saat menstruasi. 2014. Skripsi

21. Prasetyowati, Yuliawati, Katharini K. Hubungan personal hygiene dengan kejadian keputihan pada siswi SMU Muhamadiyah Metro angkatan tahun 2009. Jurnal Kesehatan Metro Sai Wawai. 2010;2(2).

22. Manuaba IBG. Kepaniteraan klinik obstetri dan ginekologi. Ed 2. Jakarta: EGC; 2004.

23. Irianto, Koes. Kesehatan reproduksi. Bandung: Alfabeta; 2015

24. Kholid, Ahmad. Promosi kesehatan. Jakarta: Rajawali Pers; 2015. 